University of Nebraska - Lincoln

DigitalCommons@University of Nebraska - Lincoln

Faculty Publications: Department of Entomology

Entomology, Department of

$12-1-2003$

\title{
Chinch Bug-Resistant Buffalograss: An Investigation of Tolerance, Antixenosis, and Antibiosis
}

\author{
Tiffany Heng-Moss \\ University of Nebraska-Lincoln, thengmoss2@unl.edu \\ Frederick P. Baxendale \\ University of Nebraska-Lincoln, fbaxendale1@unl.edu \\ Terrance P. Riordan \\ University of Nebraska-Lincoln, triordan1@unl.edu \\ Linda J. Young \\ University of Nebraska-Lincoln, lyoung3@unl.edu \\ Kit Lee \\ University of Nebraska-Lincoln
}

Follow this and additional works at: https://digitalcommons.unl.edu/entomologyfacpub

Part of the Entomology Commons

Heng-Moss, Tiffany; Baxendale, Frederick P.; Riordan, Terrance P.; Young, Linda J.; and Lee, Kit, "Chinch Bug-Resistant Buffalograss: An Investigation of Tolerance, Antixenosis, and Antibiosis" (2003). Faculty Publications: Department of Entomology. 115.

https://digitalcommons.unl.edu/entomologyfacpub/115

This Article is brought to you for free and open access by the Entomology, Department of at DigitalCommons@University of Nebraska - Lincoln. It has been accepted for inclusion in Faculty Publications: Department of Entomology by an authorized administrator of DigitalCommons@University of Nebraska - Lincoln. 


\title{
Chinch Bug-Resistant Buffalograss: An Investigation of Tolerance, Antixenosis, and Antibiosis
}

\author{
TIFFANY M. HENG-MOSS,${ }^{1}$ FREDERICK P. BAXENDALE, TERRANCE P. RIORDAN ${ }^{2}$ \\ LINDA YOUNG ${ }^{3}$, AND KIT LEE ${ }^{4}$
}

Department of Entomology, University of Nebraska, Lincoln, NE 68583

\begin{abstract}
J. Econ. Entomol. 96(6): 1942-1951 (2003)
ABSTRACT Choice and no-choice studies were conducted to determine the categories (antibiosis, antixenosis, and tolerance) of resistance of four buffalograsses (NE91-118, 'Bonnie Brae', 'Cody', and 'Tatanka') previously identified as resistant to the western chinch bug, Blissus occiduus Barber. Antibiosis studies found no significant differences in western chinch bug fecundity, nymphal development, or survival among the resistant and susceptible buffalograsses. Tolerance studies indicated that NE91-118, Cody, and Tatanka exhibited moderate-to-high levels of tolerance based on western chinch bug damage ratings and plant height, whereas Bonnie Brae exhibited moderate-to-low levels of tolerance. Choice studies indicated the presence of antixenosis in NE91-118, whereas Cody and Tatanka showed little or no antixenosis. Scanning electron microscopy was used to disclose morphological differences between NE91-118 (resistant) and '378' (susceptible). The epicuticular wax structures and trichome densities were similar between 378 and NE91-118, suggesting that morphological structures do not contribute to NE91-118 antixenosis.
\end{abstract}

KEY WORDS plant resistance, Blissus occiduus, Buchloë dactyloides

Buffalograss, Buchloë dactyloides (Nuttall) Engelmann, is an attractive alternative turfgrass species because of its low maintenance requirements and excellent drought tolerance (Riordan et al. 1996). Although few arthropods are injurious to buffalograss, the western chinch bug, Blissus occiduus Barber, has emerged as an important insect pest of this warmseason grass (Baxendale et al. 1999). The development of turfgrasses with resistance to insects offers an attractive approach for managing buffalograss-infesting chinch bugs because it is sustainable, environmentally responsible, and fits well with buffalograss' low maintenance, reduced pesticide input philosophy.

Differences in levels of resistance to insects have been reported for most major turfgrass species (Baker et al. 1981, Reinert 1982, Johnson-Cicalese et al. 1989, Quisenberry 1990, Johnson-Cicalese et al. 1998), and studies have been undertaken to characterize the categories (antibiosis, antixenosis, and tolerance) of resistance for these turfgrasses (Smith 1989). Suggested categories of turfgrass resistance have included increased tolerance because of altered resource reallocation and greater rhizome number, turf density and

\footnotetext{
${ }^{1}$ E-mail: tiffany@unlserve.unl.edu.

2 Department of Agronomy and Horticulture, University of Nebraska, Lincoln, NE 68583.

${ }^{3}$ Department of Biometry, University of Nebraska, Lincoln, NE 68583.

${ }^{4}$ School of Biological Sciences, University of Nebraska, Lincoln, NE 68588 .
}

vigor; antibiosis factors involving both chemical and morphological plant defenses that result in insect mortality, reduced oviposition, and an extended life cycle; and antixenosis factors such as pubescence, surface waxes, and leaf size and width that adversely affect the behavior of the insect (Baker et al. 1981, Reinert 1982, Johnson-Cicalese et al. 1989, Smith et al. 1994, Johnson-Cicalese et al. 1998).

Greenhouse and field experiments designed to assess the susceptibility of selected buffalograss germplasm to B. occiduus have characterized 'Cody', 'Tatanka', 'Bonnie Brae', and the experimental selection NE 91-118 as resistant to B. occiduus (Heng-Moss et al. 2002). Although these four cultivars/selections were shown to be chinch bug-resistant, studies are needed to identify the categories of this resistance. This information is essential for understanding the morphological, physiological, and biochemical mechanisms underlying the resistance, and to expedite the germplasm screening process. The objectives of this research were to characterize the categories of $B . o c$ ciduus resistance among resistant buffalograsses and to enhance our understanding of the underlying resistance mechanisms.

\section{Materials and Methods}

Choice and no-choice studies were conducted to determine the relative levels of tolerance, antibiosis, 
and antixenosis among four chinch bug-resistant buffalograsses (Heng-Moss et al. 2002).

Tolerance Studies. Tolerance Study 1. Two experiments were conducted to document levels of tolerance among the following resistant buffalograsses: Cody, Tatanka, Bonnie Brae, and NE91-118. Sod plugs, $10.6 \mathrm{~cm}$ in diameter by $6 \mathrm{~cm}$ in depth, of each resistant buffalograss and a chinch bug-susceptible control NE84-45-3 (Heng-Moss et al. 2002) were extracted from buffalograss evaluation plots at the John Seaton Anderson Turfgrass and Ornamental Research Facility (JSA Facility), University of Nebraska Agricultural Research and Development Center, near Mead, NE. Individual buffalograss plants were separated from the plugs and were planted in SC-10 Super Cell Single Cell Cone-tainers $(3.8 \mathrm{~cm}$ in diameter by $21 \mathrm{~cm}$ in depth) (Stuewe \& Sons, Inc., Corvallis, OR) containing a potting mixture of sand-soil-peat-perlite in a 0.66 : 0.33:1:1 ratio. Cone-tainers were placed in 7 by 14 cone-tainer trays under 400-Watt high-intensity discharge lamps with a photoperiod of 16:8 (L:D) $\mathrm{h}$. Plants were fertilized biweekly with a soluble (20.0: 4.4:16.6, N-P-K) fertilizer.

Fifth instars of chinch bugs were collected from an infested NE84-45-3 buffalograss evaluation plot at the JSA Facility with a DC insect vacuum (model 820B, BioQuip, Gardena, CA). Chinch bugs were sifted through a 2-mm mesh screen and collected with an aspirator. To acclimate chinch bugs to growth chamber conditions, chinch bugs were maintained on 15-cm pots of NE84-45-3 for $24 \mathrm{~h}$ before beginning each experiment.

The experimental design was a completely randomized design with three replications per experiment. The treatment design was a 5 by 2 factorial (five buffalograss cultivars/selections and two levels of chinch bug infestation). Experiments were conducted in a growth chamber that was maintained at $28 \pm 2^{\circ} \mathrm{C}$ with a photoperiod of 16:8 (L:D) h.

At the onset of both experiments, plants were paired according to similar heights and turf quality. Chinch bugs (equal ratio of males and females) at two infestation levels (six or 12) were introduced on one plant of each buffalograss pair, whereas the second plant served as the uninfested control. Tubular, Plexiglas cages $(4 \mathrm{~cm}$ in diameter by $30 \mathrm{~cm}$ in height) were used to confine chinch bugs on plants.

Plants were rated for chinch bug damage at the beginning of both experiments and every day thereafter by using a $1-5$ scale, where 1 is $10 \%$ or less damage, 2 is 11 to $30 \%, 3$ is 31 to $50 \%, 4$ is 51 to $70 \%$, and 5 is $71 \%$ or more damage and plant close to death. Experiments were terminated after $14 \mathrm{~d}$. At that time, the total number of chinch bugs on each buffalograss selection was determined by examining all buffalograss tillers and the soil in each cone-tainer for the presence of chinch bugs. Plant heights and dry weights were also determined for all selections at the end of the experiment. Plant biomasses were determined after placing the plant material in an oven at $60^{\circ} \mathrm{C}$ for $48 \mathrm{~h}$.
Chinch bug damage ratings, plant heights, and biomasses were used to calculate two functional plant loss indices (FPLIs) (Morgan et al. 1980, Panda and Heinrichs 1983) and to assess the suitability of these indices for detecting buffalograss tolerance to $\mathrm{B}$. occiduus. Unfortunately, most indices developed to quantify tolerance in agronomic crops are based on yield and have limited applicability for turfgrasses where plant esthetics is the primary criterion for assessing turfgrasses for resistance to insects (Shortman et al. 2002). The indices evaluated in these studies were selected because they included an esthetic (damage rating) component.

FPLI (biomass) $=1-$ (biomass of infested plant/

$$
\text { biomass of control plant) }
$$$$
\times(1-\text { damage rating } / 5) \times 100
$$

FPLI (height) $=1-$ (height of infested plant $/$

$$
\text { height of control plant) }
$$

$$
\times(1-\text { damage rating } / 5) \times 100
$$

For both of these indices, low FPLI values indicate plant tolerance, whereas high values signify lack of tolerance.

Tolerance Study 2. An additional tolerance study was conducted to assess the levels of tolerance in NE91-118, Cody, and Tatanka. Sod plugs, $10.6 \mathrm{~cm}$ in diameter by $6 \mathrm{~cm}$ in depth, of these buffalograsses and NE84-45-3 (susceptible control) were collected from buffalograss evaluation plots. Plugs were trimmed to the soil surface, planted in 15-cm pots, and maintained as previously described. Bonnie Brae was not included in this study because plant material was no longer available.

Chinch bugs were collected from an infested NE8445-3 evaluation plot at the JSA Facility as described above. Chinch bugs were maintained on pots of NE8445-3 for $24 \mathrm{~h}$ before beginning the experiment. Fifty fifth instars of chinch bugs were placed on plants at the start of the experiment. Tubular cages of clear acetate, $12 \mathrm{~cm}$ in diameter by $30 \mathrm{~cm}$ in height were used as a barrier for inclusion of chinch bugs. Cage tops were covered with organdy fabric secured with a rubber band. Plants were maintained in a growth chamber at $28 \pm 2^{\circ} \mathrm{C}$ with a photoperiod of $16: 8$ (L:D) h throughout the study.

The experimental design was a randomized complete block design with six replications. Plants were rated for chinch bug damage (1-5 scale) at the start of the study and every day thereafter. The experiment was terminated and plants harvested when susceptible plants had a damage rating of four or higher. The total number of chinch bugs on each buffalograss selection was assessed by placing the plant material in Berlese funnels (Southwood 1978) for $48 \mathrm{~h}$ to extract the chinch bugs.

Statistical Analyses. Mixed model analyses (PROC MIXED, SAS Institute 1997) were conducted for each tolerance index and chinch bug damage rating to de- 
tect treatment differences (Littell et al. 1996). Where appropriate, means were separated using Fisher's least significant difference (LSD) procedure.

Antibiosis Studies. Fecundity, nymphal development, and chinch bug survival were used to assess levels of antibiosis among the resistant buffalograsses (Cody, Tatanka, and NE91-118). The chinch bug-susceptible '378' (Heng-Moss et al. 2002) was included in the antibiosis studies as the control.

Antibiosis Study 1. Two separate experiments were conducted to evaluate chinch bug fecundity as a measure of antibiosis in the resistant buffalograsses. Individual plants from plugs of each cultivar/selection collected from buffalograss evaluation plots at the JSA Facility were planted in SC-10 Super Cell Single Cell Cone-tainers $(3.8 \mathrm{~cm}$ in diameter by $21 \mathrm{~cm}$ in depth) (Stuewe \& Sons, Inc.) and maintained as described previously. Adult chinch bugs were collected from a 378 evaluation plot also at the JSA Facility. Field collected chinch bugs were maintained on $15-\mathrm{cm}$ pots of 378 for $24 \mathrm{~h}$ before beginning each experiment to acclimate them to growth chamber conditions. At the onset of both experiments, four adult chinch bugs (equal ratio of males and females) were placed on each plant. Tubular Plexiglas cages $(4 \mathrm{~cm}$ in diameter by $30 \mathrm{~cm}$ in height) served as a barrier for inclusion of chinch bugs. Plants were maintained in a growth chamber with a temperature of $28 \pm 2^{\circ} \mathrm{C}$ and a photoperiod of 16:8 (L:D) h.

Experiments were terminated after $3 \mathrm{wk}$, and the total number of offspring was recorded. The total number of chinch bugs on each buffalograss selection was assessed by examining every buffalograss tiller and the soil in each cone-tainer for the presence of chinch bugs. The experimental design was a randomized complete block design with six replications per experiment.

Antibiosis Study 2. A second antibiosis study was carried out to assess the long-term antibiotic effects of the resistant cultivars/selections on chinch bug fecundity. Individual plants from plugs of each cultivar/ selection were planted in SC-10 Super Cell Single Cell Cone-tainers $(3.8 \mathrm{~cm}$ in diameter by $21 \mathrm{~cm}$ in depth) (Stuewe \& Sons, Inc.), and maintained as described in study 1 .

A cohort of adult chinch bugs (25 males and 25 females) was maintained on each resistant buffalograss and the susceptible (378) control for one complete generation before initiating the study. Four newly emerged adult chinch bugs (two males and two females) were introduced on the buffalograss plant in each cone-tainer at the start of the study. A tubular Plexiglas cage ( $4 \mathrm{~cm}$ in diameter by $30 \mathrm{~cm}$ in height) ensured inclusion of chinch bugs.

The study was conducted in a growth chamber that was maintained at $28 \pm 2{ }^{\circ} \mathrm{C}$ with a photoperiod of $16: 8$ (L:D) h. The experimental design was a randomized complete block design with six replications. The study was terminated after $3 \mathrm{wk}$, and the total number of chinch bug offspring was recorded.

Antibiosis Study 3. Two additional experiments were conducted to detect antibiotic effects of resistant buffalograsses on nymphal development and chinch bug survival. Individual plants from plugs of each buffalograss (Cody, Tatanka, NE91-118, and 378) were planted in Single Cell Cone-tainers $(3.8 \mathrm{~cm}$ in diameter by $21 \mathrm{~cm}$ in depth) (Stuewe \& Sons, Inc.) and maintained as described previously. Plugs of each cultivar/selection were collected from buffalograss evaluation plots at the JSA Facility. A total of 10 newly hatched $(<10 \mathrm{~h})$ chinch bug nymphs collected from the pots of 378 were introduced on each cone-tainer at the start of the experiment by using a camel's-hair brush (Mize and Wilde 1986).

Experiments were conducted in a growth chamber that was maintained at $28 \pm 2{ }^{\circ} \mathrm{C}$ with a photoperiod of 16:8 (L:D) h. The experimental design was a randomized complete block design with six replications per experiment. Nymphal survival and age class distribution of the chinch bugs were recorded at $32 \mathrm{~d}$ after chinch bug introduction.

Statistical Analyses. Mixed model analyses (PROC MIXED, SAS Institute 1997) were conducted to detect differences in the number of offspring produced, nymphal development, and chinch bug survival (Littell et al. 1996). Where appropriate, means were separated using Fisher's LSD procedure.

Antixenosis Studies. Antixenosis Study 1. F our choice experiments were conducted under growth chamber conditions to document chinch bug preference for selected buffalograsses. Ten buffalograsses (378, NE86-61, NE86-120, NE91-118, NE84-45-3, Cody, Tatanka, Texoka, 609, and 315) were evaluated for preference by B. occiduus.

Chinch bugs were collected from an infested 378 evaluation plot at the JSA Facility. To acclimate chinch bugs to growth chamber conditions, field-collected chinch bugs were maintained on $15-\mathrm{cm}$ pots of 378 for $24 \mathrm{~h}$ before beginning each experiment.

Plugs of each cultivar/selection were collected from buffalograss evaluation plots at the JSA Facility. Individual buffalograss plants were separated from the plugs and placed in vials $(1.7 \mathrm{~cm}$ in diameter by $9 \mathrm{~cm}$ in depth) of water and sealed with a rubber stopper (1.7 $\mathrm{cm}$ in diameter). Vials were then inserted into 1.7-cm-diameter holes drilled into a circular test arena $(33.5 \mathrm{~cm}$ in diameter by $8.5 \mathrm{~cm}$ in depth). Each test arena contained at least one vial of each cultivar/ selection. Twenty-five fifth instars of chinch bugs were released in the center of each test arena. The number of chinch bugs on each buffalograss cultivar/ selection was visually documented at 1, 2, 4, 8, 24, 48, and $72 \mathrm{~h}$ after chinch bug introduction.

Experiments were conducted in a growth chamber that was maintained at $28 \pm 2^{\circ} \mathrm{C}$ with continuous light. The experimental design was a randomized incomplete block design with 10 replications per experiment.

Antixenosis Study 2. Two additional choice experiments were carried out to further document chinch bug preference. These experiments were conducted in a growth chamber maintained at $28 \pm 2{ }^{\circ} \mathrm{C}$ with continuous light. The experimental design was a ran- 
domized complete block design with 10 replications per experiment.

NE86-120 and NE91-118 were evaluated for preference by $B$. occiduus. These two selections had previously been identified as the most and least preferred buffalograsses in the initial choice study. Ten plugs of each cultivar/selection, $10.6 \mathrm{~cm}$ in diameter by $6 \mathrm{~cm}$ in depth, were extracted from buffalograss evaluation plots at the JSA Facility. Individual buffalograss plants were separated from the plugs and were placed in 2.5-ml vials of water and sealed with Parafilm (American National Can, Greenwich, CT). One vial of each cultivar/selection was placed on opposite sides of a round plastic test arena $(15.5 \mathrm{~cm}$ in diameter by $7 \mathrm{~cm}$ in depth). Vials were fastened to the arena surface by using hot wax. Ten fifth instars of chinch bugs, collected from an infested 378 buffalograss evaluation plot at the JSA Facility, were released in the center of each test arena. The number of chinch bugs on each buffalograss selection was visually determined at 0.5 , $1,2,3,4,8$, and $24 \mathrm{~h}$ after chinch bug introduction.

Statistical Analysis. Mixed model analyses (PROC MIXED, SAS Institute 1997) was conducted to identify differences in chinch bug preference among resistant and susceptible buffalograsses (Littell et al. 1996). Where appropriate, means were separated using Fisher's LSD procedure.

Scanning Electron Microscopy Studies. Scanning electron microscopy (SEM) was used to disclose morphological differences between resistant and susceptible buffalograsses. Specifically, SEM served to reveal epicuticular leaf structures (leaf pubescence and epicuticular waxes) of NE86-120, NE91-118 and 609. Selections were included based on previously conducted choice studies in which NE91-118 and 609 were the least chinch bug-preferred buffalograsses evaluated and NE86-120 was the most preferred. The chinch bug-susceptible cultivar 378 was also included in this study.

Two plugs of each cultivar/selection, $10.6 \mathrm{~cm}$ in diameter by $6 \mathrm{~cm}$ in depth, were collected from buffalograss evaluation plots at the JSA Facility. Plugs were trimmed to the soil surface and planted in $15-\mathrm{cm}$ pots. Plants were maintained under greenhouse conditions with a photoperiod of 16:8 (L:D) h and average temperature of $24 \pm 3^{\circ} \mathrm{C}$.

Four weeks after trimming, five 1-cm leaf sections of new growth were extracted from each buffalograss evaluated. Each section was cut $1 \mathrm{~cm}$ from the leaf sheath on the third fully expanded leaf blade. The adaxial and abaxial surfaces were examined for trichomes and wax structures.

Leaf segments were fixed in $3 \%$ glutaraldehyde in $0.1 \mathrm{M}$ phosphate buffer ( $\mathrm{pH} 7.2$ ) for $24 \mathrm{~h}$. Tissues were then dehydrated in an ethanol series $(25,50,70,90,95$, and $100 \%$ ) and critical-point dried with $\mathrm{CO}_{2}$ in a bomb apparatus (Sorvall, Newton, CT). Leaf segments were placed on aluminum stubs and coated with 200-A $\mathrm{Au}-\mathrm{Pd}$. The trichomes and wax structures of each buffalograss were examined and photographed on the SEM (STEREOSCAN 90, Cambridge Instruments,
London, United Kingdom) at the School of Biological Sciences (University of Nebraska, Lincoln).

\section{Results}

Tolerance Studies. Tolerance Study 1. Mixed model analysis detected no significant differences $(P>0.05)$ between experiments 1 and 2 ; therefore, the data were pooled. Statistically significant differences in the FPLI index based on plant biomass were detected among the buffalograsses ( six chinch bugs: $F=3.8$; $\mathrm{df}=4,29$; $P<0.02 ; 12$ chinch bugs: $F=5.4 ; \mathrm{df}=4,29 ; P<0.001)$. However, the relative ranking of index values were not consistent with observed damage ratings for the cultivars/selections. This probably occurred because of variability in initial root densities and plant vigor among buffalograss plants of the same cultivar/selection. Therefore, this index was deemed unsuitable as a measure of chinch bug tolerance in buffalograss.

Significant differences in the FPLI (based on plant height) were also detected among the buffalograsses evaluated for the two chinch bug infestation levels (six chinch bugs: $F=3.7$; df $=4,29 ; P<0.001 ; 12$ chinch bugs: $F=2.1$; $\mathrm{df}=4,29 ; P<0.04$ ) (Fig. 1). The FPLI was highest for NE84-45-3 at both infestation levels, indicating a lack of chinch bug tolerance. The resistant buffalograsses had significantly lower FPLI values at the lower chinch bug infestation level compared with NE84-45-3 (susceptible), indicating the presence of tolerance in these cultivars/selections. At the higher infestation level, Bonnie Brae's FPLI value was not significantly different from the susceptible control, probably reflecting excessive chinch bug pressure. Cody, Tatanka, and NE91-118 had higher FPLI values at the higher infestation level, but were still significantly different from NE84-45-3.

Damage ratings proved to be an effective measurement for assessing tolerance among resistant buffalograsses. Statistically significant differences in chinch bug damage ratings were detected among the buffalograsses evaluated for both infestation levels (six chinch bugs: $F=7.62$; df $=9,59 ; P<0.0001 ; 12$ chinch bugs: $F=19.16$; $\mathrm{df}=9,59 ; P<0.0001$ ) (Table 1 ). No significant differences in chinch bug damage were observed between Cody, Tatanka, Bonnie Brae, and NE91-118 plants infested at the lower chinch bug level and their respective controls. At the higher chinch bug infestation level, however, damage ratings for the resistant buffalograsses were significantly different from their uninfested controls. This likely resulted when chinch bug pressure (12 per plant) exceeded the plant's ability to tolerate B. occiduus feeding.

Tolerance Study 2. Significant differences in chinch bug damage ratings were detected among the buffalograsses evaluated $(F=10.55 ; \mathrm{df}=7,47 ; P<0.001)$ (Table 2). Both control and infested NE91-118 plants had similar chinch bug damage ratings, suggesting the presence of tolerance in this selection. Chinch bug damage ratings were significantly different between control and infested plants for Cody and Tatanka. Unlike vegetatively propagated buffalograsses (e.g. NE91-118) that has little genetic diversity, seeded 


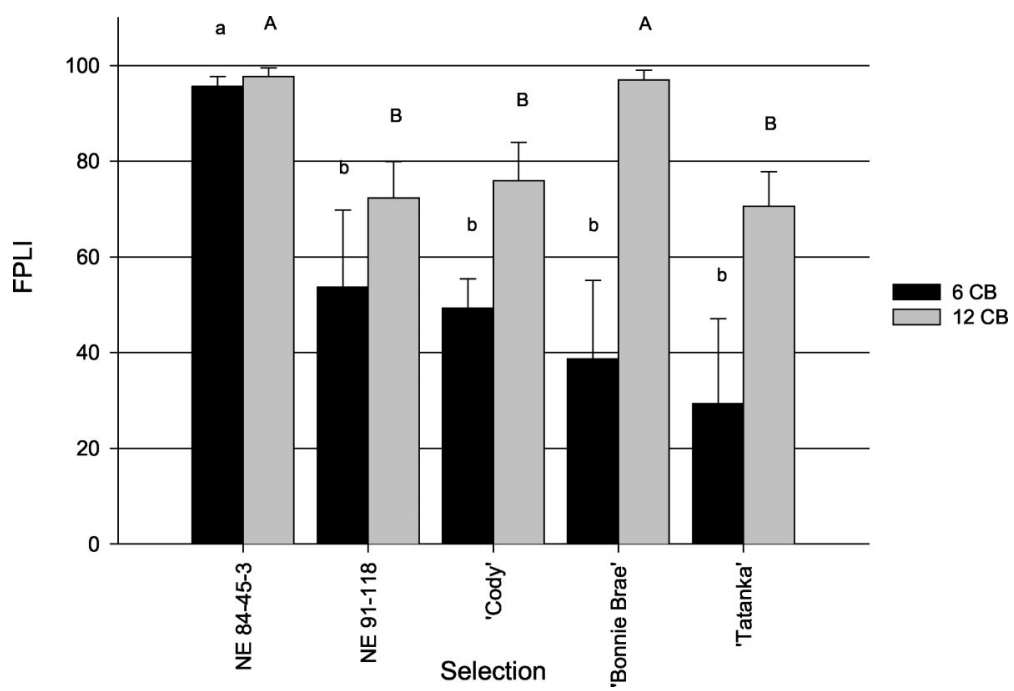

Fig. 1. FPLI values based on plant height. Bars with the same letter in the same case are not significantly different at $P>$ 0.05 , LSD test.

buffalograsses such as Cody and Tatanka are developed from multiple parents that may vary in their levels of resistance to B. occiduus. Consequently, seeded buffalograss stands are comprised of many genotypes and often exhibit substantial genetic diversity. These genotypic differences help explain the higher level of susceptibility for Cody and Tatanka in this study.

Antibiosis Studies. Antibiosis Study 1. Mixed model analysis detected no significant differences $(P>0.05)$ between the two experiments, therefore, the data were pooled. There were no significant differences in the number of chinch bugs produced on the resistant and susceptible buffalograsses $(F=0.54 ; \mathrm{df}=3,47 ; P<$ 0.71 ). Mean number of offspring produced ( \pm SEM) were $28.4 \pm 5.6,28.7 \pm 7.0,30.4 \pm 5.6$, and $31.1 \pm 6.6$ for 378, Cody, NE91-118, and Tatanka, respectively. These results indicate little or no antibiosis in the buffalograsses evaluated.

Antiboisis Study 2. There were no significant differences in the number of chinch bugs produced on the buffalograsses in this study $(F=0.60$; $\mathrm{df}=3,23$; $P<0.62)$. Mean number of offspring produced

Table 1. Comparison of $\boldsymbol{B}$. occiduus damage ratings between control and infested buffalograsses (studies 1 and 2)

\begin{tabular}{lccccc}
\hline \hline \multirow{2}{*}{ Selection } & \multicolumn{4}{c}{ Chinch bug damage ratings ${ }^{a}$} \\
\cline { 2 - 3 } & \multicolumn{2}{c}{ Chinch bugs (6) } & & Chinch bugs (12) \\
\cline { 2 - 3 } \cline { 5 - 6 } & Infested & Control & & Infested & Control \\
\hline NE84-45-3 & $4.2 \mathrm{a}$ & $1.0 \mathrm{c}$ & & $4.8 \mathrm{a}$ & $1.0 \mathrm{c}$ \\
NE91-118 & $1.9 \mathrm{bc}$ & $1.0 \mathrm{c}$ & & $2.9 \mathrm{~b}$ & $1.0 \mathrm{c}$ \\
Cody & $1.8 \mathrm{bc}$ & $1.0 \mathrm{c}$ & & $3.1 \mathrm{~b}$ & $1.0 \mathrm{c}$ \\
Bonnie Brae & $1.6 \mathrm{bc}$ & $1.0 \mathrm{c}$ & & $4.6 \mathrm{a}$ & $1.0 \mathrm{c}$ \\
Tatanka & $1.3 \mathrm{c}$ & $1.0 \mathrm{c}$ & & $2.7 \mathrm{~b}$ & $1.0 \mathrm{c}$ \\
\hline
\end{tabular}

Means within columns and rows (at the same infestation level) followed by the same letter are not significantly different $(P>0.05$, LSD test).

${ }^{a}$ Chinch bug damage rating $1-5$ scale; 1 , no damage.
$( \pm$ SEM $)$ were $15.3 \pm 5.1,18.5 \pm 6.2,24.0 \pm 12.4$, and $25.0 \pm 5.6$ for NE91-118, 378, Cody, and Tatanka, respectively.

Antibiosis Study 3. Mixed model analysis detected no significant differences $(P>0.05)$ between the two experiments, therefore, the data were pooled. Nymphal development and chinch bug survival were not affected by buffalograss cultivar/selection (nymphal development: $F=2.10 ; \mathrm{df}=3,47 ; P<0.10$ and chinch bug survival: $F=1.7 ; \mathrm{df}=3,47 ; P<0.2$ ) (Fig. 2). These studies demonstrate that the resistant buffalograsses in this study do not adversely affect chinch bug development and indicate a lack of antibiosis.

Antixenosis Studies. Antixenosis Study 1. Mixed model analysis detected no significant differences $(P>0.05)$ among the four antixenosis experiments so the data were pooled. A significant interaction between buffalograss treatment and time $(F=1.59 ; \mathrm{df}=$ $60,2,326 ; P<0.003)$ was detected. This interaction reflects a decrease in chinch bug numbers on the more preferred buffalograsses at 48 and $72 \mathrm{~h}$ after introduction. Apparently, chinch bugs moved to the less preferred buffalograsses in response to declining turf quality resulting from chinch bug feeding.

Table 2. Comparison of $\boldsymbol{B}$. occiduus damage ratings for selected buffalograsses (study 3 )

\begin{tabular}{lcc}
\hline \hline \multirow{2}{*}{ Selection } & \multicolumn{2}{c}{ Chinch bug damage $^{a}$} \\
\cline { 2 - 3 } & Infested & Control \\
\hline NE84-45-3 & $4.7 \mathrm{a}$ & $1.0 \mathrm{~d}$ \\
Tatanka & $2.2 \mathrm{~b}$ & $1.0 \mathrm{~d}$ \\
Cody & $1.8 \mathrm{bc}$ & $1.0 \mathrm{~d}$ \\
NE91-118 & $1.3 \mathrm{~cd}$ & $1.0 \mathrm{~d}$ \\
\hline
\end{tabular}

Means within columns and rows followed by the same letter are not significantly different ( $P>0.05$, LSD test).

${ }^{a}$ Chinch bug damage rating $1-5$ scale; 1 , no damage. 


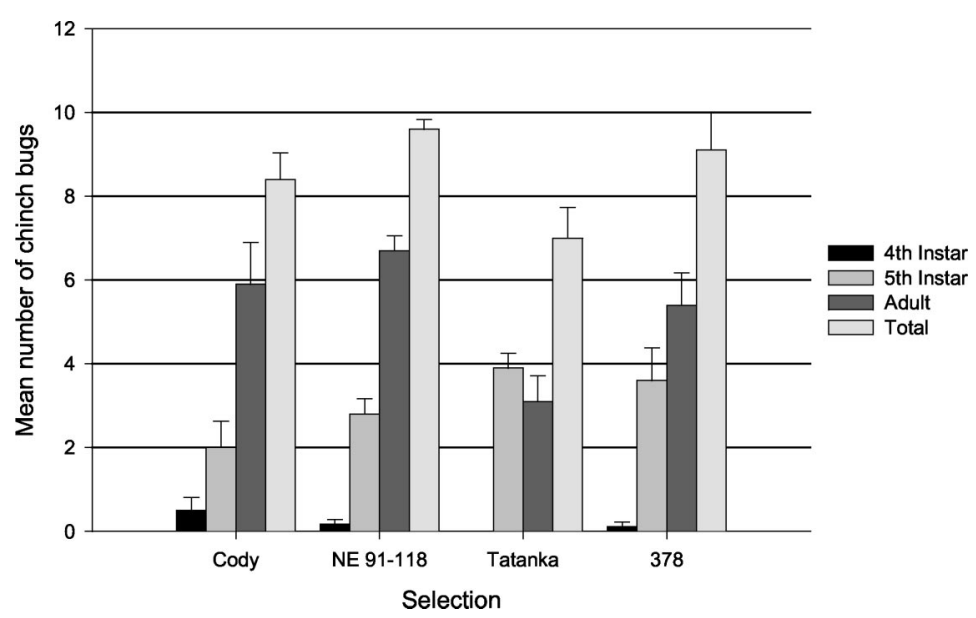

Fig. 2. Survival of chinch bugs by age class $32 \mathrm{~d}$ after introduction of first instars on resistant and susceptible (378) buffalograsses.

Significant differences in chinch bug preference were observed among the buffalograsses $(F=4.62$; $\mathrm{df}=60,2326 ; P<0.0001)$ and evaluation times $(F=$ $4.22 ; \mathrm{df}=60,2326 ; P<0.0003)$. The greatest differences were detected at 24 and $48 \mathrm{~h}$ after chinch bug introduction. NE86-120 was consistently the most preferred selection beginning at $4 \mathrm{~h}$ after introduction, whereas NE91-118 and 609 were less preferred (Fig. 3). This study established that NE 91-118 and 609 display antixenosis, whereas Cody, Tatanka, as well as the other six cultivars/selections evaluated exhibit little or no antixenosis.

Antixenosis Study 2. Mixed model analysis detected no significant differences $(P>0.05)$ between the two experiments so the data were pooled. NE86-120 again consistently had more chinch bugs than NE91-118 $(F=18.2 ; \mathrm{df}=21,339 ; P<0.0001)$ (Fig. 4). The greatest differences in chinch bug numbers between the two selections were observed at the first three evaluations. The mean number of chinch bugs ranged from 0.6 to 0.9 and 1.3 to 2.1 for NE91-118 and NE86120 , respectively. This study further demonstrates that NE91-118 displays antixenosis.

Scanning Electron Microscopy. Epicuticular wax structures were similar among NE86-120, 609, 378, and NE91-118 (Fig. 5); however, wax density varied. NE86-120 and 609 had lower wax densities than NE91118 and 378. Visual differences in trichome densities were evident (Figs. 6 and 7). The cultivar 609 had almost no trichomes, whereas the other three buffalograsses had similar trichome densities $\left(\approx 6 / \mathrm{mm}^{2}\right)$. These observations suggest that morphological structures such as trichome density and epicuticular wax do not contribute to NE91-118 antixenosis.

\section{Discussion}

This research provides essential information for characterizing antixenotic and tolerant mechanisms of resistance to $B$. occiduus. Choice and no-choice ex-

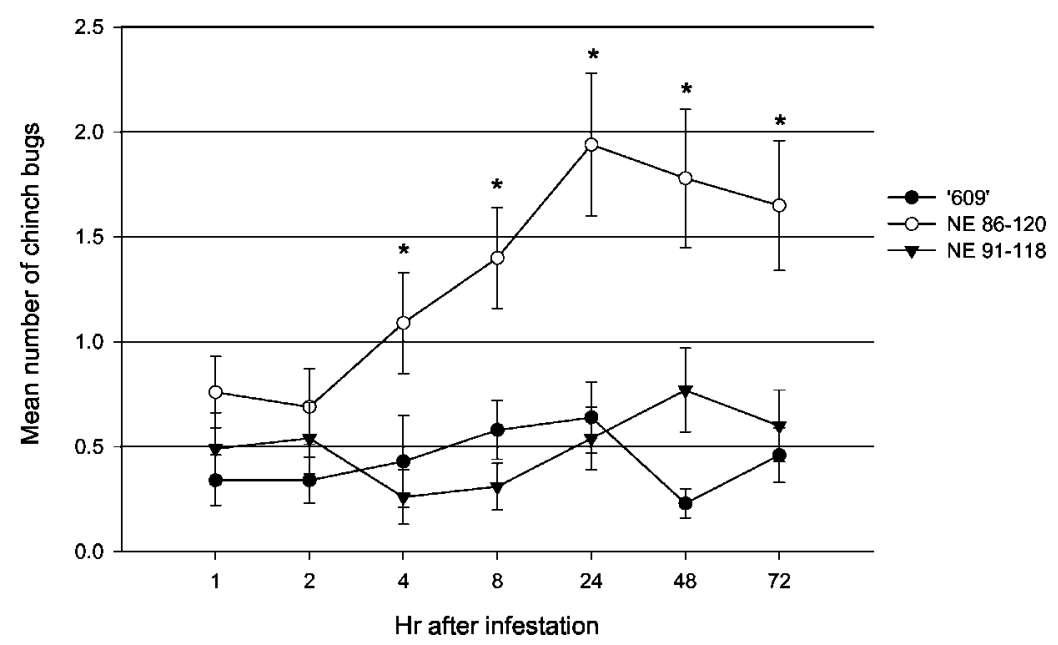

Fig. 3. Comparison of chinch bug preference for selected buffalograsses. *Significantly different at $P<0.05$, LSD test. 


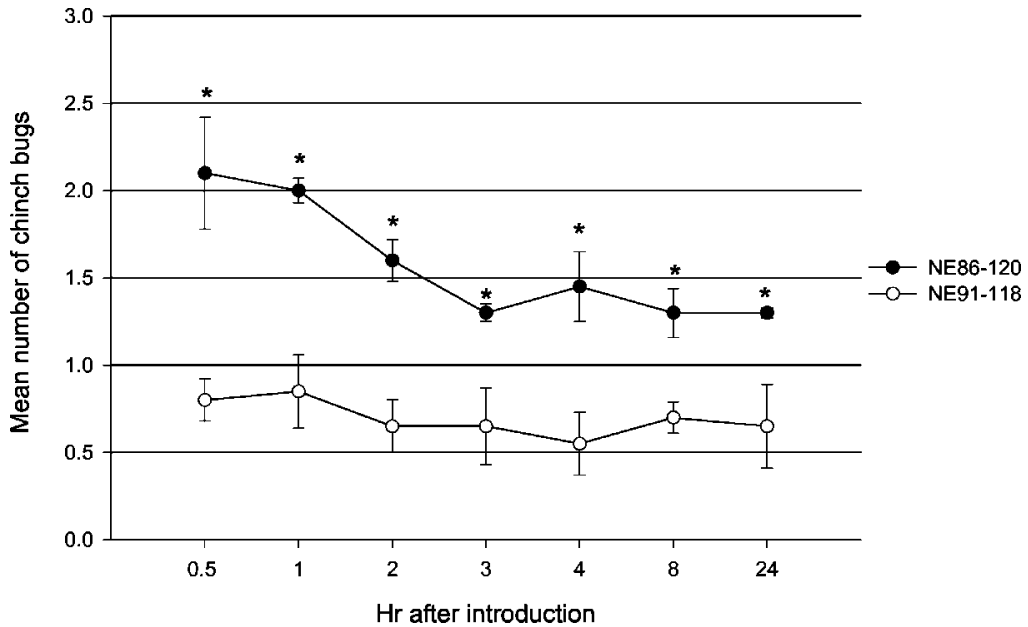

Fig. 4. Comparison of chinch bug preference between NE86-120 and NE91-118. *Significantly different at $P<0.05$, LSD test.

periments served to assess the relative levels of antibiosis, antixenosis, and tolerance among the resistant buffalograsses. Cody and Tatanka were identified as tolerant, whereas NE91-118 showed both tolerance and antixenosis.
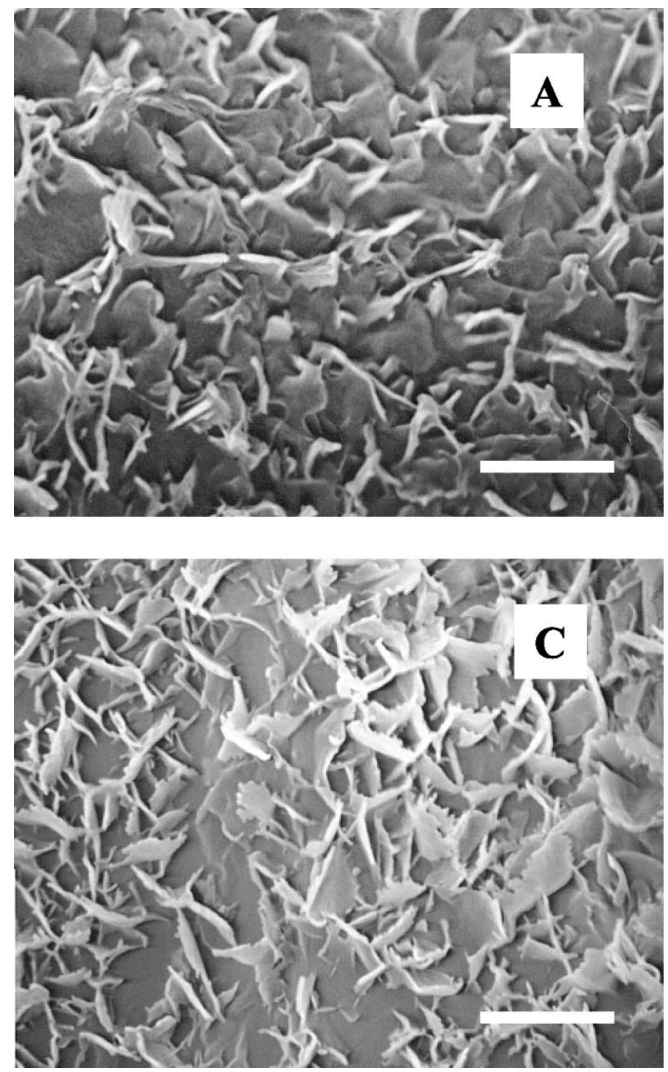

No-choice experiments assessed levels of chinch bug tolerance. Among the buffalograss cultivars/selections evaluated NE91-118, Cody, and Tatanka were designated as tolerant to B. occiduus feeding. Chinch bug damage ratings and FPLI values based on plant
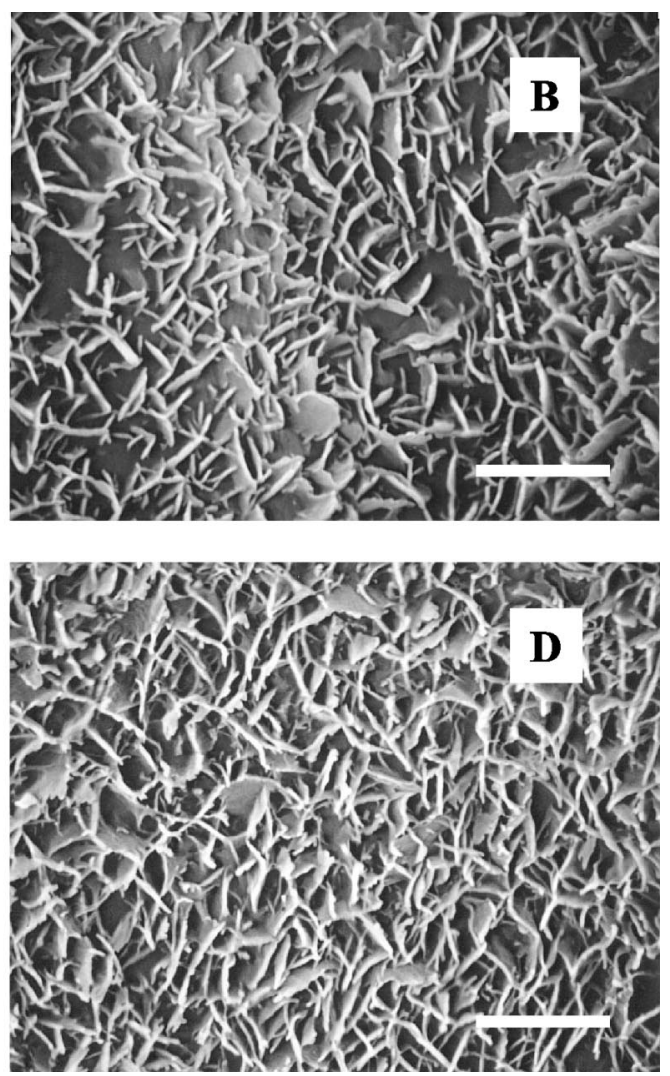

Fig. 5. Overview of epicuticular wax ultrastructures of selected buffalograsses: (A) 609, (B) NE91-118, (C) NE86-120, and (D) 378. Scale bar, $10 \mathrm{~mm}$. 

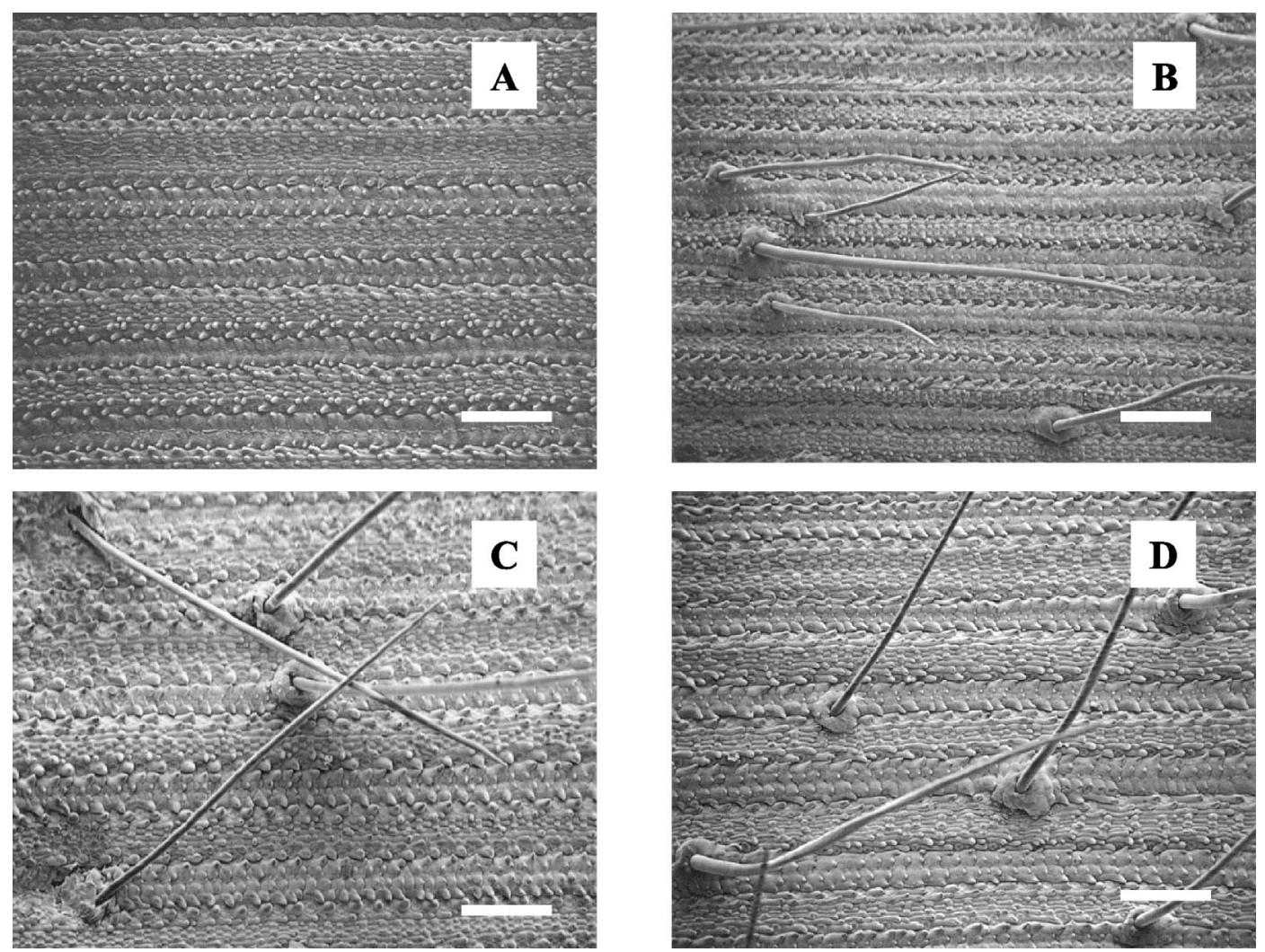

Fig. 6. Overview of adaxial leaf surface of selected buffalograsses: (A) 609, (B) NE91-118, (C) NE86-120, and (D) 378. Scale bar, $0.1 \mathrm{~mm}$.

height were identified as the most useful parameters for assessing buffalograss tolerance to chinch bugs.

Unfortunately, only a limited number of studies have been carried out to assess tolerance levels among other chinch bug resistant turfgrasses. Baker et al. (1981) and Ratcliffe (1982) reported on several Kentucky bluegrass cultivars exhibiting tolerance to Blissus leucopterus hirtus Montandon. They measured tolerance by comparing height of regrowth, dry weight, yield of clippings, root length, and tillering. Although all these parameters are important measurements of the physiology and growth of the turfgrass plant, esthetics, an equally or more important parameter, was not assessed in these studies. Our research found that plant esthetics is a valuable indicator of buffalograss tolerance and should be considered when assessing turfgrass tolerance to chinch bugs.

Antibiosis studies evaluated differences in chinch bug fecundity, nymphal development, and chinch bug survival among the buffalograsses. No significant differences in any of these parameters were found between the resistant and susceptible buffalograsses investigated. This suggests that antibiosis is not an important category of the buffalograss resistance to $B$. occiduus. It is interesting to note, however, that antibiosis was identified as the category of resistance for St. Augustinegrass (Stenotaphrum secundatum [Walt.] Kuntze.) resistant to B. insularis Barber (Reinert and
Dudeck 1974, Reinert et al. 1980). Although our research did not identify antibiosis in NE91-118, Cody, or Tatanka, given the substantial genetic diversity of buffalograss, chinch bug-resistant buffalograsses identified in the future should continue to be assessed for antibiosis.

Choice studies revealed the number of chinch bugs selecting NE91-118 and 609 was significantly lower than the other buffalograsses tested, indicating the presence of antixenosis. Johnson-Cicalese et al. (1998) identified 609 as resistant to the mealybugs, Tridiscus sporoboli (Cockerell) and Trionymus spp. and cited antixenosis as responsible for this resistance (JohnsonCicalese 1995). They speculated that glabrous leaves contributed to 609's mealybug resistance. SEM observations revealed no visual differences in leaf wax structures, but trichome densities were different among the buffalograsses examined. Although trichome densities were similar for NE91-118, NE86120 , and 378, the leaf blades of 609 had fewer trichomes and were characterized as glabrous. Further studies are needed to fully examine the epicuticular leaf structures of 609 and further characterize antixenotic mechanisms for chinch bug and mealybug resistance.

This research provides valuable information on the mechanisms of chinch bug resistance in buffalograss. In addition, the information obtained thus far has 

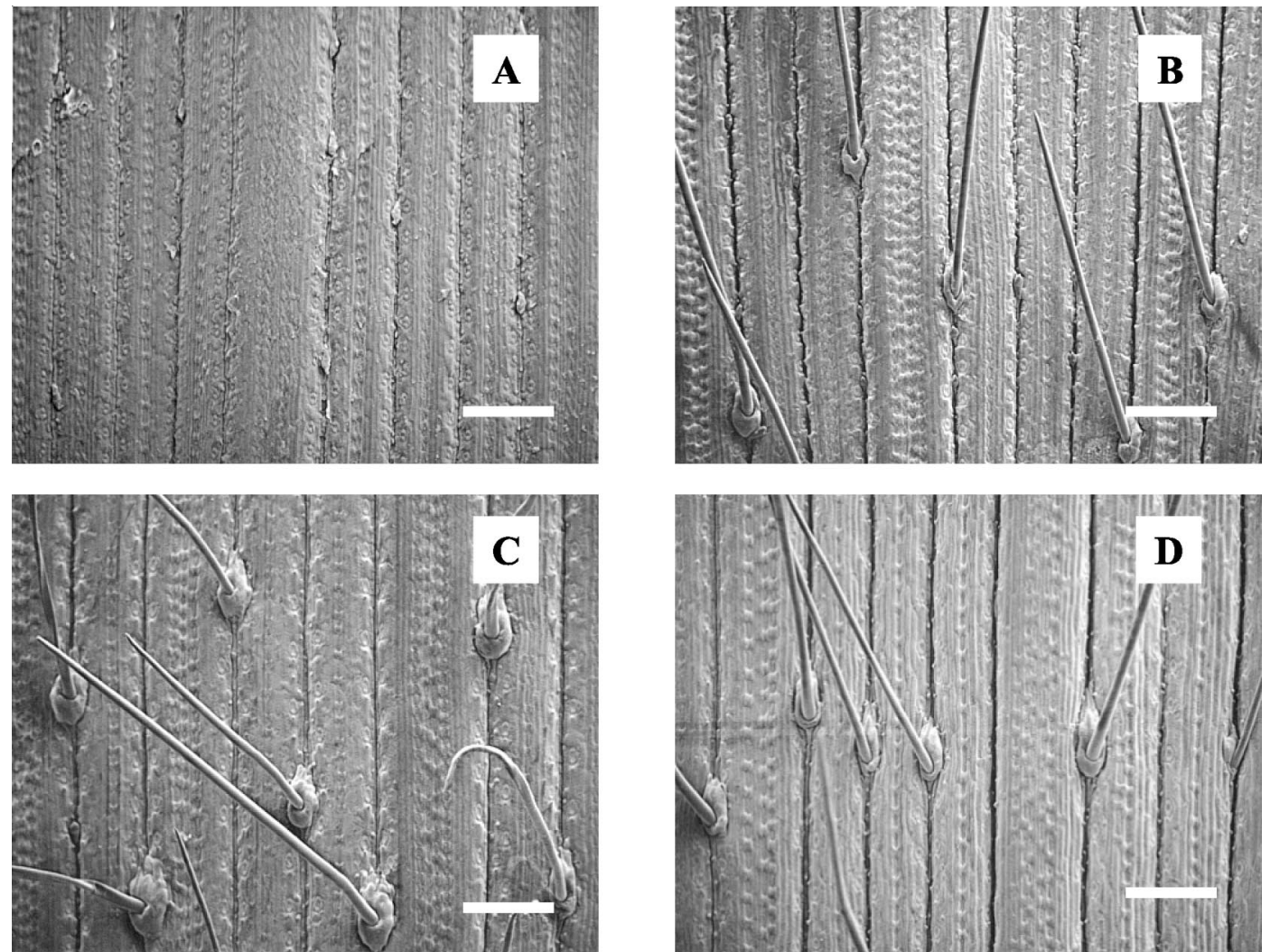

Fig. 7. Overview of abaxial leaf surface of selected buffalograsses: (A) 609, (B) NE91-118, (C) NE86-120, and (D) 378. Scale bar, $0.1 \mathrm{~mm}$.

provided new avenues for further investigation. Specifically, future studies should focus on improving our understanding of tolerant and antixenotic mechanisms for buffalograss NE91-118.

\section{Acknowledgments}

We acknowledge D. Keith and T. Hunt for reviewing this manuscript, and T. Weinhold, T. Eickhoff, and L. Witt (University of Nebraska) for technical assistance. This research was supported in part by the University of Nebraska Agricultural Experiment Station Project 17-051 and 17-078, the United States Golf Association, and the Nebraska Turfgrass Foundation. This is paper number 14106 of the journal series of the Agricultural Research Division, University of Nebraska-Lincoln.

\section{References Cited}

Baker, P. B., R. H. Ratcliffe, and A. L. Steinhauer. 1981. Tolerance to hairy chinch bug (Blissus leucopterus) feeding in Kentucky bluegrass (Poa pratensis). Environ. Entomol. 10: 153-157.

Baxendale, F. P., T. M. Heng-Moss, and T. P. Riordan. 1999. Blissus occiduus Barber (Hemiptera: Lygaeidae): a new chinch bug pest of buffalograss turf. J. Econ. Entomol. 92: $1172-1176$

Heng-Moss, T. M., F. P. Baxendale, T. P. Riordan, and J. E. Foster. 2002. Evaluation of buffalograss germplasm for resistance to Blissus occiduus. J. Econ. Entomol. 95: 10541058.

Johnson-Cicalese, J. M. 1995. Buffalograss resistance to mealybugs: germplasm evaluation, mechanisms, and inheritance. Ph.D. dissertation, University of Nebraska, Lincoln, NE.

Johnson-Cicalese, J. M., R. H. Hurley, G. W. Wolfe, and C. R. Funk. 1989. Developing turfgrasses with improved resistance to billbugs, pp 107-111. In 6th International Turfgrass Research Conference, July 31-Aug. 5, Tokyo, Japan. Japan Society of Turfgrass Science, Tokoyo, Japan.

Johnson-Cicalese, J. M., F. P. Baxendale, T. P. Riordan, and T. M. Heng-Moss. 1998. Identification of mealybug (Homoptera: Pseudococcidae)-resistant turf-type buffalograss germplasm. J. Econ. Entomol. 91: 340-346.

Littell, R. C., G. A. Milliken, W. W. Stroup, and R. D. Wolfinger. 1996. SAS system for mixed model. SAS Institute, Cary, NC.

Mize, T. W., and G. Wilde. 1986. New grain sorghum sources of antibiosis to the chinch bug (Heteroptera: Lygaeidae). J. Econ. Entomol. 79: 176-180.

Morgan, J., G. Wilde, and D. Johnson. 1980. Greenbug resistance in commercial sorghum hybrids in the seedling stage. J. Econ. Entomol. 73: 510-514.

Panda, N., and E. A. Heinrichs. 1983. Levels of tolerance and antibiosis in rice varieties having moderate resistance to the brown planthopper, Nilaparvata lugens (Stål) (Hemiptera: Delphacidae). Environ. Entomol. 12: $1204-$ 1214. 
Quisenberry, S.S. 1990. Plant resistance to insects and mites in forage and turfgrasses. Fla. Entomol. 73: 411-421.

Ratcliffe, R. H. 1982. Evaluation of cool-season turfgrasses for resistance to the hairy chinch bug, pp. 13-18. In H. D. Niemczyk and B. G. Joyner [eds.], Advances in turfgrass entomology. Hammer Graphics, Inc., Piqua, $\mathrm{OH}$.

Reinert, J. A. 1982. A review of host resistance in turfgrasses to insects and acarines with emphasis on the southern chinch bug, pp. 3-12. In H. D. Niemczyk and B. G. Joyner [eds.], Advances in turfgrass entomology. Hammer Graphics, Inc., Piqua, $\mathrm{OH}$.

Reinert, J. A., and A. E. Dudeck. 1974. Southern chinch bug resistance in St. Augustine-grass. J. Econ. Entomol. 67: 275-277.

Reinert, J. A., B. D. Burton, and R. W. Toler. 1980. Resistance of St. Augustinegrass to southern chinch bug and St. Augustine decline strain of Panicum mosaic virus. J. Econ. Entomol. 73: 602-604.

Riordan, T. P., F. P. Baxendale, R. E. Gaussoin, and J. E. Watkins. 1996. Buffalograss: an alternative native grass for turf. Coop. Ext., University of Nebraska-Lincoln, NE. G96-1297-A.

SAS Institute. 1997. SAS/STAT Software: changes and enhancements through release 6.12. SAS Institute, Cary, NC.

Shortman, S. L., S. K. Braman, R. R. Duncan, W. W. Hanna, and M. C. Engelke. 2002. Evaluation of turfgrass species and cultivars for potential resistance to twolined spittlebug (Hemiptera: Cercopidae). J. Econ. Entomol. 95: 478486.

Smith, C. M. 1989. Plant resistance to insects. Wiley, New York.

Smith, C. M., Z. R. Khan, and M. D. Pathak. 1994. Techniques for evaluating insect resistance in crop plants. Lewis Publishers, Boca Raton, FL.

Southwood, T.R.E. 1978. Ecological methods. Halsted, New York.

Received for publication 24 June 2003; accepted 28 August 2003. 